\title{
LATENT EMPLOYEE TURNOVER AND Prevention-When Job Creation Catches Up with Economic Recovery: An Employee Retention Model and Case Study
}

\author{
Barry A. Friedman and Lisa M. Schnorr
}

\author{
Barry A. Friedman* \\ Professor, Organizational Behavior and \\ Human Resource Management \\ State University of New York at Oswego \\ barry.friedman@oswego.edu \\ Lisa M. Schnorr \\ Senior Vice President, Finance and Controller \\ Constellation Brands, Inc. \\ Lisa.Schnorr@cbrands.com
}

Barry Friedman is corresponding author

\begin{abstract}
Most employees perform well, are solid organizational citizens, and possess valued intellectual capital. However, this critical mass of employees is at risk due to their experiences over the past two decades (e.g., reductions in force and developmental
\end{abstract}


funding) and its associated reduction in organizational loyalty and commitment. Job creation lags behind economic recoveries. As the economy generates more jobs, more employees leave their organizations for better employment opportunities. We introduce the concept of latent employee turnover- the potential exodus of valued employees in the near future, and ways leaders can retain valued employees. An employee retention model is offered followed by an organizational case study, Constellation Brands, Inc., to illustrate effective employee retention practices.

Keywords: latent employee turnover, unemployment

\section{INTRODUCTION}

Most employees perform well, are solid organizational citizens, possess valued intellectual capital, and contribute to organizational effectiveness. This critical mass of employees is at risk due to their collective experience over the past two decades and negative lessons learned about their diminished value. These experiences include countless reductions in force, slashed training and development expenditures, reduced promotional opportunities brought about by flattened organizational structures, pay stagnation, and pay inequities (e.g., executives rewarded total compensation packages worth hundreds of times the value of average employees). Such experiences may reduce organizational loyalty and commitment. In the recent past, the employment psychological contract favored employers when unemployment was high, job openings were scarce, and employees believed that alternative external employment opportunities were few. The ultimate employee reaction to this psychological contract is to leave their organization and seek employment elsewhere; however, quitting is problematic if few external employment opportunities exist. Tekleab, Orvis and Taylor (2013) showed that adverse changes in employees' perceived psychological contracts had negative effects, including increased turnover intentions, reduced job satisfaction and organizational loyalty. However, the psychological contract leverage may shift towards employees as more jobs are created following 
economic recoveries. The loss of intellectual capital is a significant cost to organizations (Kraemer \& Gouthier, 2014; Alexandrov, Babakus, \& Yavas, 2007). This cost is increased when competitors hire employees that quit (Moreno, Torres \& Vargas, 2015).

Job creation lags behind economic recovery as reflected in such indicators as major stock indices (e.g., DJA, S\&P 500) and macroeconomic indicators (e.g., GDP). As recently as late 2013, the DJA reached record levels, but the unemployment rate stagnated and the number of new jobs generated failed to meet expectations. By 2015, new job creation increased over 200,000 monthly for 12 straight months and the unemployment rate fell to 5.5\% in February, the lowest since May, 2008 (BLS, 2015; Maurer, 2015b). While the low unemployment rate is questionable (e.g., the rate doesn't comprehend underemployment or the unemployed that give up their job search), there exists a general consensus that unemployment is declining (Jackson, 2015). Jackson (2015) argues that there exist three signs of economic recovery: declining unemployment, strong job creation, and quit rates. When these three stars align, what will be the consequences of low organizational commitment and loyalty brought about by the negative organizational practices listed above?

As new jobs are created, it's likely that employees will perceive that external job opportunities exist. This perception may then result in active job searches. In their seminal work, March and Simon (1958) argued that employees seek and take alternative employment if they perceive that better jobs are available. A general myth is that employees don't test the job market in poor economies with fewer available jobs. This is only partly correct. The job market will always be better for top talent who are more marketable, more confident, have more employment alternatives than average employees, and are therefore more likely than their average counterparts to leave in any economy. This is true whether the economy is growing or contracting: there is typically a favorable market for excellent performers. The concept presented below, latent employee turnover, 
pertains to all employees that possess intellectual capital. That is, latent employee turnover pertains to all employees and not just top talent.

\section{LAtent Turnover}

We introduce the concept of latent employee turnover- the potential exodus of valued employees in the near future, and ways leaders can retain valued employees. Employee adverse organizational practices such as layoffs may have resulted in employee beliefs that they are not valued, that the employment-at-will doctrine makes them expendable commodities, and that their psychological contracts have changed to their disadvantage. Employees may believe that they therefore must protect themselves and self-interest becomes paramount. These organizational practices may have eroded employee organizational commitment, decreased loyalty, and increased latent employee turnover. As early as 2012, the majority of employees was dissatisfied with their organizations and was already preparing to quit (Kelly, 2012).

We are still recovering from the toxic mortgage crisis that significantly damaged the economy. Undaunted by this lesson, economists warn that toxic auto and student loans present similar dangers. It seems that easy credit has migrated from home to auto and student loans. However, the emphasis on toxic loans has taken management's eye off another looming crisis that threatens organizations' ability to compete: latent turnover that is hidden and threatens organizational competitiveness. Like the iceberg that sunk the Titanic, latent employee turnover threatens organizations by lurking below the water line- hidden but dangerous.

\section{EMPLOYEE TURNOVER, UNEMPLOYMENT AND GDP}

Several models exist that emphasize the psychological antecedents of employee turnover (Price, 1977; Mobley, 1977; Mobley, Griffeth, Hand \& Meglino, 1979). Recent research have explored the relationships among 
economic activity and turnover. Moreno, Torres and Vargas (2015) found that job turnover was positively correlated with Gross Domestic Product (GDP) and inversely correlated with unemployment. That is, increases in the economy are related to lower unemployment and more employees leaving their positions for better opportunities. Moreno, Torres and Vargas (2015, page 11) state that:

"when the economy has a positive growth path, the turnover rate is higher at the prospect of finding work in companies that rehire or new establishments that initiate operations; in contrast, when the economy has a downturn, labor turnover rates decrease, given the shortage of vacancies in the market or the processes of layoffs"

Lazear and Spletzer (2012) distinguish between voluntary turnover (when employees quit) and churning, which occurs as employees move to other positions where they can add greater value and are replaced (i.e., no net new job growth). Drawing from the Job Openings and Labor Turnover Survey (JOLTS) microdata, Lazear and Spletzer (2012) state that

"Churn declines during recessions because separations, which during good times would have been associated with a replacement hire, are allowed to go unfilled during recessions. As a result, employment declines. Churn also declines during recessions because workers become reluctant to quit their jobs, and in response businesses reduce their hiring. Hiring declines during recessions. During the 2007-09 recession, four-fifths of hiring reductions were associated with reduced churn, not with reductions in job creation" (page 575).

The cost of churn is high in that employee movement to more productive uses of their intellectual capital slows during recessions and high unemployment. Conversely, churning increases during economic recoveries and GDP growth as employees leave their positions for better opportunities.

Leamer (2008) argued that economic downturns lead to loss of jobs, higher unemployment in the short term, and adversely impact the long 
term supply of certain occupations. With respect to nursing jobs in the healthcare industry, Alameddine, Baumann, Laporte and Deber (2012) propose that economic downturns decrease demand, increase supply, freeze or decrease salaries, and decrease turnover.

Conversely, economic recoveries may be associated with job creation and reduction in layoffs (Maurer, 2015a). While most research suggests that increases in job creation following economic recoveries, a minority of researchers argues that new job creation is volatile (Abo-Zaid, 2014). Moscarini and Postel-Vinay (2009) report that many employees terminated by large organizations during recessions are subsequently hired by small organizations during economic recoveries. Camacho, Quiros and Mendizabal (2011) argue that intense job creation followed economic recoveries during the eighties, but slower job creation followed recoveries since that time. Summers (2010) also finds that job creation will follow recovery, albeit slowly. There appears a general consensus that job creation follows economic recoveries, only slower than in previous recoveries.

\section{Employee Retention Model}

Retention of valued employees in the face of latent employee turnover requires strategic leadership and strategic human resource management. While latent turnover threatens to decrease organizational competitiveness, leaders can take steps to reduce the threat. Figure 1 contains a model of employee retention (i.e., latent turnover prevention). Human resource systems such as staffing and employee development exist within a macroorganizational context. The model's outer ring contains four contextual elements: organizational culture and values, total rewards, mentoring, and retention tracking. Organizational culture has been shown to be related to employee intention to leave and retention (Vafeas, 2015; FleigPalmer and Rathert, 2015; Timms et al., 2015; Ahmed, Pavani, and Kumar, 2014; Inabinett and Ballaro, 2014; Santora, 2009). Total rewards, including financial and non-financial rewards, are also associated with employee 
retention (Giannetti and Metzger, 2015; Korsakiene, Stankeviciene, Simelyte \& Talackiene, 2015; Treuren, and Frankish, 2014; Milman and Dickson, 2014; Singh and Natasha, 2010). Mentoring refers to the process by which experienced employees assist less experienced employees. Mentoring with respect to job performance, career planning and mobility is associated with employee retention (Flynn, Mathis, Jackson and Valentine, 2016; Wang, Hu, Hurst, and Yang, 2014; Reinstein, Sinason, and Fogarty, 2012). While not a contextual element, retention tracking, as part of a larger Human Resource Management System (HRIS), is a sound management practice that can identify turnover risks and help plan organizational responses.

Within the contextual variables described above, Figure 1 contains human resource management practices that occur during employees' life cycle. That is, employees' organizational lives begin with recruitment and selection, experience various onboarding activities (e.g., new employee orientation), complete training and development processes, progress through their careers, and finally leave the organization.

Effective human resource initiatives that are aligned with organizational objectives and effectively implemented have been linked to positive employee job commitment, low turnover intent, and organizational effectiveness (Kim, Wehbi, DelliFraine \& Brannon, 2014; Wheeler, Halbesleben, \& Harris, 2012; Friedman, 2009; Friedman, 2007; Becker, Huselid, \& Ulrich, 2001; Urlich, 1997). Figure 2 contains specific effective human resource management suggestions intended to decrease latent employee turnover at each stage of the employee life cycle.

\section{RECRUITMENT}

Recruitment refers to establishing a pool of qualified and diverse job applicants. Best practices for recruitment include identifying effective recruitment sources, establishing networks within these sources, and establishing effective recruiting messages and methods (e.g., job fairs, 
Internet, social media). In order to reduce short term turnover, Wanous $(1992,1980)$ introduced realistic job previews to the recruiting process. Realistic job previews provide applicants with information needed to make an informed job acceptance decision (Earnest, Allen, \& Landis, 2011). Baur, Buckley, Bagdasarov and Dharmasiri (2014) maintain that realistic job previews add value to worker socialization programs.

The use of e-recruiting has recently increased (e.g., Facebook and LinkedIn). After reviewing the use of e-recruiting, Melanthiou, Pavlou, and Constantinou (2015, page 31) concluded that a "well-designed system and strategic utilization of available information about potential candidates may significantly assist the recruitment of employees with the most suitable skills and competencies."

\section{Selection}

Selection refers to the process of selecting individuals from the applicant pool. Following a period of time where organizations were concerned about bias and discrimination, tests are commonly used in the selection process (Halzack, 2014). The literature is replete with effective selection techniques, including job information inventories, interviews (Maurer \& Solamon, 2006; Huffcutt \& Woehr, 1999; Schmidt \& Rader, 1999), written tests (e.g., cognitive, aptitude, personality), and simulations (e.g., assessment centers). Of special note is the use of effective job analysis, job relatedness of employment tests, and empirical test validation (i.e., test validity and reliability) of all techniques used by decision makers to make an employment decision.

\section{ONBOARDing}

Onboarding is the process of socializing new employees to organizational expectations and culture. Onboarding represents an opportunity for the organization and the new employee to make positive first impressions. 
Graybill, Hudson Carpenter, Offord, Piorun, and Shaffer (2013) reported that typical onboarding activities include company overviews (e.g., mission, vision and objectives), introduction to key personnel, and initial training. Cable, Gino, and Staats (2013) argue that organizations should encourage new employees to express their unique job perspectives and strengths early in the onboarding process. Smith et al. (2013) found that positive feedback from peers and supervisors early in the onboarding process was related to positive new employee coping strategies and reduced turnover intentions.

\section{Training and Development}

Training and development refer to short term job specific skill building and long term career competency building, respectively. Best practices in this domain include effective needs assessment, selection and delivery of effective and efficient methods, and evaluation of training results. Alignment of training and organizational objectives is very important, as well as reinforcement of learning outcomes in the workplace that promote transfer of learning, especially with respect to training conducted off the job. Peter and Eunice (2014) demonstrated that effective training and development practices are associated with such positive outcomes as increased organizational commitment. Yean and Yahya (2013) reported a positive relationship between training and development practices and career satisfaction.

\section{Career Management}

Career management refers to the programs and activities that facilitate the progression of employees through careers. Such programs and activities include career pathing, mentoring, developmental action plans, and succession plans. The long term nature of career planning sends a message to employees that organizations value them, invest in their long term employee development, and promote from within. The deployment of a 
human resource management system as a tool in the planning process is also important to identify internal candidates for internal promotion. Baek-Kyoo and Ready (2012) found that employee goal orientation, perceived organizational learning culture, and favorable supervisory relationships were associated with career satisfaction.

\section{Exit Planning}

The final stage of the employee life cycle occurs as employees leave the organization. Organizations often ignore the process by which valued employees leave. Exit planning include conducting and analyzing exit interviews and retirement planning. Causes of turnover and actions to increase retention can be gleamed during exit interviews of employees that voluntarily leave (Neal, 1989). Retirement plans may include goal setting, financial advice concerning relocation, savings, employee benefits, investment, and budgeting. The psychological challenges associated with retirement may also be addressed, such as establishing new networks, social support, and time use. Employees may believe that such activities and assistance may be indicative of a long term organizational concern for their valued employees, and hence may increase organizational commitment and reduce latent employee turnover. A case study of one organization's concerted efforts to retain its valued employees is offered below.

\section{Case Study -Constellation Brands, Inc.}

Constellation Brands (NYSE: STZ and STZ.B) is a leading international producer and marketer of beer, wine and spirits with operations in the U.S., Canada, Mexico, New Zealand and Italy. In 2015, Constellation was one of the top performing stocks in the S\&P 500 Consumer Staples Index. Constellation is the number three beer company in the U.S. with high-end, iconic imported brands including Corona Extra, Corona Light, Modelo Especial, Negra Modelo and Pacifico. Constellation is also the world's 
leader in premium wine selling great brands that people love including Robert Mondavi, Clos du Bois, Kim Crawford, Meiomi, Mark West, Franciscan Estate, Ruffino and Jackson-Triggs. The company's premium spirits brands include SVEDKA Vodka and Black Velvet Canadian Whisky (Constellation Brands, 2016).

Constellation Brands' voluntary employee turnover is well below the average for Consumer Packaged Goods (CPG) industrial sector. According to recent survey data, the average annual voluntary turnover within the U.S. consumer products sector was 8\% for 2011-2014 (Elkjaer \& Filmer, 2015), while the Constellation Brands' average U.S. turnover was just under $6 \%$ for the same time period. What accounts for Constellation Brands' employee retention effectiveness?

\section{CONTEXTUal Factors}

Using the Employee Retention model presented earlier (Figures 1 \& 2 ), several contextual factors drive employee retention (the model's outer ring). Constellation's market performance is a significant factor in attracting and retaining employees. STZ has outperformed the S\&P 500 in 12 of the last 15 years. Constellation Brands operates within the dynamic, fast-paced beverage and alcohol industry (beer, wine and spirits). The U.S. beverage alcohol industry is growing at more than twice the rate of other CPG companies. During the 52 weeks ended Jan 4, 2015, the U.S. beverage alcohol sector dollar value grew 3-4\%, while the overall CPG sector dollar value grew approximately 1.4\% (Information Resources, Inc., 2015).

Constellation Brands' organizational culture and ownership structure also contribute to employees' desire to remain with the company. The company has a high percentage of family ownership and family management involvement. Constellation was founded 70 years ago by Marvin Sands and throughout its 70-year history, there have been only three Chief Executive Officers, all of whom are Sands family members. Marvin Sands served as President and CEO until 1994; his son, Richard Sands 
served as President and CEO from 1994 until 2007 and in 2007, Richard's brother, Robert Sands, was appointed President and CEO and continues to serve in that role today. Despite growth and leadership succession, Constellation Brands' works to remain a small company culture and feel despite its growth to more than 8,000 employees worldwide.

Corporate social responsibility, employee engagement and employee retention are closely related (Slack, Corlett \& Morris, 2015; Kusuma \& Sukanya, 2013; Turker, 2009; Berger, Cunningham, \& Drumwright, 2006). Constellation Brands and the Sands family have a long and generous philanthropic history and encourage company employees to give back to the communities in which they live and work. Employees are proud to work for such a giving company. Corporate social responsibility is highly valued as evidenced by the Constellation Brands' active support of the community, including significant contributions to The V Foundation for Cancer Research, F.F. Thompson Hospital and Rochester General Hospital in New York, the Heart and Stroke Foundation of Canada and the Ride to Conquer Cancer in Canada, the American Diabetes Association's Tour de Cure, Constellation Marvin Sands Performing Arts Center (CMAC), the New York Wine \& Culinary Center, Haiti earthquake relief efforts, Habitat for Humanity, United Way, and many others institutions and causes.

Another important contextual factor driving employee retention is Constellation Brands' Total Rewards program is designed to attract, motivate and retain employees. The company base salaries are competitive and generally targeted at the market median; high performing employees and those considered to be "experts in their fields" have the opportunity to earn salaries toward the high end of the salary range and well above market median.

The company also offers competitive short-term cash incentives with the ability to earn higher payouts for higher levels of company and individual performance and an equity compensation program goes deep in the company. During times of high growth and/or strong performance, the equity compensation program has been a significant differentiator in 
the marketplace, as it has resulted in significant wealth creation for many employees. Most equity awards vest over a four-year period, and has significantly contributed to long-term employee retention. There exists a significant disincentive to leave before awards become fully vested.

Other marketplace differentiators include an attractive Employee Stock Purchase Plan (ESPP) that offers the maximum allowable discount (15\%), and an annual allowance to purchase company products for purposes of promoting the company's brands with friends and family.

Performance-based equity awards are often used as a means of rewarding key employees for completion of large, strategic projects. The value of such awards can be significant, often as high as $0.5 \mathrm{x}-1 \mathrm{x}$ base salary, as these need to be meaningful enough to keep employees focused on the project objectives and timeline. The company also provides a webbased employee recognition program that allows employees to publicly recognize another employee for going above and beyond to solve a business problem or assist other employees and customers.

Lastly, the company offers competitive employee benefits that some researchers claim contribute to attracting and retaining valued employees (Mrkvicka, 2015). Constellation Brands offers employees a wide range of employee benefits, including medical, dental, vision, and 401k retirement options. While not a significant driver of employee motivation, the lack of competitive employee benefits may contribute to attrition.

The contextual factors of family ownership and stability, strong philanthropic orientation, sense of corporate social responsibility, small company feel, a comprehensive Total Rewards program, and strong financial performance are intended to retain employees. The company has also proactively invested in numerous programs intended to increase employee retention and improve engagement. For example, recognizing the link between employee engagement and retention (Swarnalatha \& Prasanna, 2013), Constellation Brands conducts periodic employee surveys to assess employee engagement and to identify action plans to improve employee engagement and retention. Using the Employee Reten- 
tion Model, several other Constellation Brands programs are described below (Figure 3).

\section{RECRUIT}

The contextual factors described above combined with Constellation Brands' public profile has made the company an employer of choice with access to a growing candidate pool over the past several years. Constellation Brands can therefore be very selective when hiring candidates for open positions. This growing candidate pool can be evidenced in the growth of the company's summer internship program over the past four years. In 2012, there were 33 applicants for 17 summer internships. In 2013, the applicant pool grew to 137 and by 2015, 1,359 applicants competed for 40 internship positions.

To support its performance management programs and help ensure the right candidates are selected for open positions, the company recently developed a competency-based model that is used throughout the various stages in the employee lifecycle (recruiting, selection, performance management, career planning, etc.). Recruiters identify candidates with the right competencies to narrow down the field of candidates and interview those exhibiting the required competencies for the role. Competencies include communication, working with others and taking initiative as well as technical competencies required to be successful in a given role.

\section{Select}

To foster retention, employees are selected and later evaluated on their ability to recognize development needs, provide challenging work assignments and develop others for more responsibility. Candidates are screened and those with the required competencies are identified using resume reviews, telephone screenings, online evaluations, and interviews. 
The competency-based model helps improve the probability for a high quality hire that will remain with the company.

\section{ONBOARD}

Constellation's new hire on-boarding class is an instructor-led comprehensive introduction to the company's industry and business, functional departments, product education and Brand Ambassadorship. During Salute, employees learn about Constellation's rich culture and history as well as the company's vision, mission, strategic imperatives and core values. The program is designed to assist employees in their assimilation into Constellation and to provide information about the company's products to give employees a comfort level with being a Constellation Brand Ambassador.

\section{DeVELOP}

Valued employees desire development opportunities, growth, increased responsibilities and promotional opportunities. Constellation Brands established an infrastructure that allows for developmental growth and career progression. A comprehensive employee, management and leadership curriculum supports employee growth needs. Classroom or online training programs are available to employees to build specific skills in many areas, including self-development, management development, leadership development, team development, and competency development. These programs target individual contributors as they develop functional competencies and other skills development; managers as they coach and manage others' performance, and leaders as they develop skills to motivate and direct large groups of employees. The company also offers support for continuing professional education programs (e.g., CPAs, attorneys, etc.), system skills training and industry-specific certifications (e.g., the Wine \& Spirits Education Trust provides employees the opportunity to grow their knowledge of the wine \& spirits industry). 
About every two years, Constellation Brands nominates approximately 30 of its high potential company leaders to participate in a formal Executive Development Program (EDP). EDP consists of a week-long classroom program conducted at Harvard University followed by participation in Action Learning Projects whereby groups of 5-6 employees work on some of the company's greatest strategic initiatives. The teams develop recommendations which are then presented to the senior leadership team for consideration. To date, more than half of the recommendations have been adopted by the company, and have resulted in new product ideas, technology solutions, or other investment ideas to grow the company. Not counting employee departures due to divestitures or reorganizations, 114 employees have participated in the EDP since 2007, and only 3 have voluntarily left the organizations. In addition to working on and addressing real business issues, participants benefit from building valuable working relationships with employees throughout the organization.

Developmental opportunities and tools exist outside the classroom. For example, informal mentor programs match employees with mentors that provide coaching, in such areas as leadership and career development.

\section{Career Management}

The company recently introduced a new Talent Management process and will complete its first cycle during Spring 2016. The purpose of this process is to assess "Bench" readiness (replacements for key positions); to identify talent gaps in the organization; and to plan for development opportunities (internal) and investments (new hires). The process involves first identifying the most critical roles in the organization and then identifying the company's key talent/high potential employees. The next step is to ensure that the most critical roles are staffed with key talent. Where this is not the case, job rotations can be planned to move key talent into critical roles. Where there is not a clear match within the organization, the company can either develop the talent internally by moving a high potential employee into a critical role "stretch" assignment to develop 
their skills; or recruit the necessary talent into the organization. The results of the talent review process can be used for deliberate, planned job rotations or when an employee vacates a critical role unexpectedly- the company can refer to its key talent roster to identify a suitable successor.

\section{Exit Plan}

The company routinely conducts exit interviews for employees that leave voluntarily. These exit interviews have provided valuable information that reinforces several of the initiatives described above.

\section{Discussion and Conclusion}

Economists point out that the current economic recovery is not unique in that job creation typically lags economic indicators. Employers often delay filling job vacancies because of market uncertainty and an emphasis on increased productivity in lieu of adding staff. Of course, people need income to buy products and use services which in turn drive demand and the economy. Jobs are critical for long term sustainable economic growth, Job growth will eventually increase, albeit at a slow pace. When employees perceive employment opportunities outside their organization, will latent turnover manifest itself, or will valued employees be retained? The most obvious employer consideration is to place greater emphasis on the long term impact on employees of all employment actions.

Future research should explore the implications of psychological contract as employees gain more leverage and latent turnover becomes actual turnover. An important variable is employee intention to leave their organizations. Turnover intent is the process of thinking, planning, and desiring to leave a job (Wheeler, Harris, \& Harvey, 2010; Steel \& Ovalle, 1984; Mobley, Griffeth, Hand, \& Meglino, 1979). Research suggests that intent to leave is a predictor of turnover (Udechukwu \& Mujtaba, 
2007) and should be studied as they relate to the turnover model presented here (Lambert, 2012).

The model depicted here lists specific programs organizations can employ to retain their most valued employees, such as those implemented by Constellation Brands. The model also suggests avenues for future research. For example, wages have not increased in proportion to the economic recovery (Jackson, 2015; Coombs, 2015). Contributing further to a climate of income inequality, executive compensation has increased disproportionally more than the average workforce (typically averaging $3 \%$ over the last few years). Pay has recently become the most important factor contributing to employee dissatisfaction (SHRM, 2013a, SHRM, 2013b). The impact of pay, size of pay increases, perceived inequity, and income inequality on turnover intentions when external opportunities are believed to exist is but one avenue of study. Similar avenues for future research include the impact of latent employee turnover for staffing, career pathing, leadership, motivation and other human resource practices. 
Figure 1. Employee Retention Model

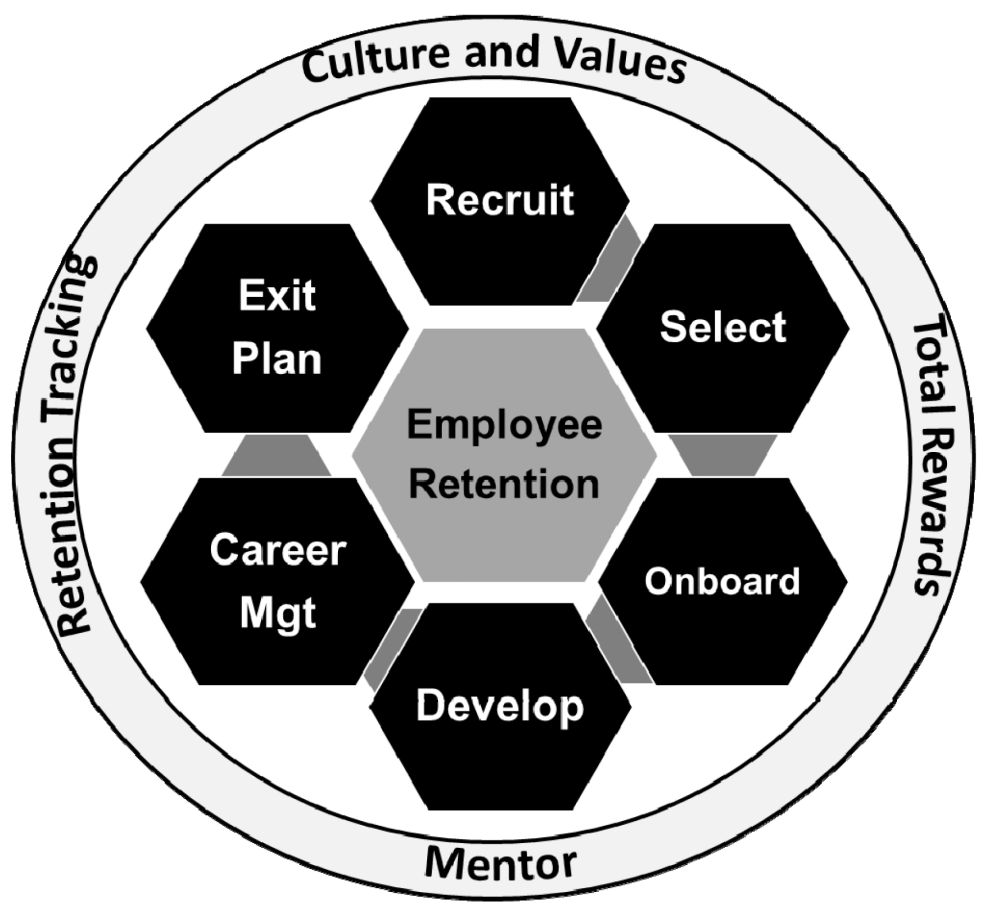


20 The BRC Academy Journal of Business Vol. 6, No. 1

Figure 2. Effective Human Resource Practices that Promote Employee Retention

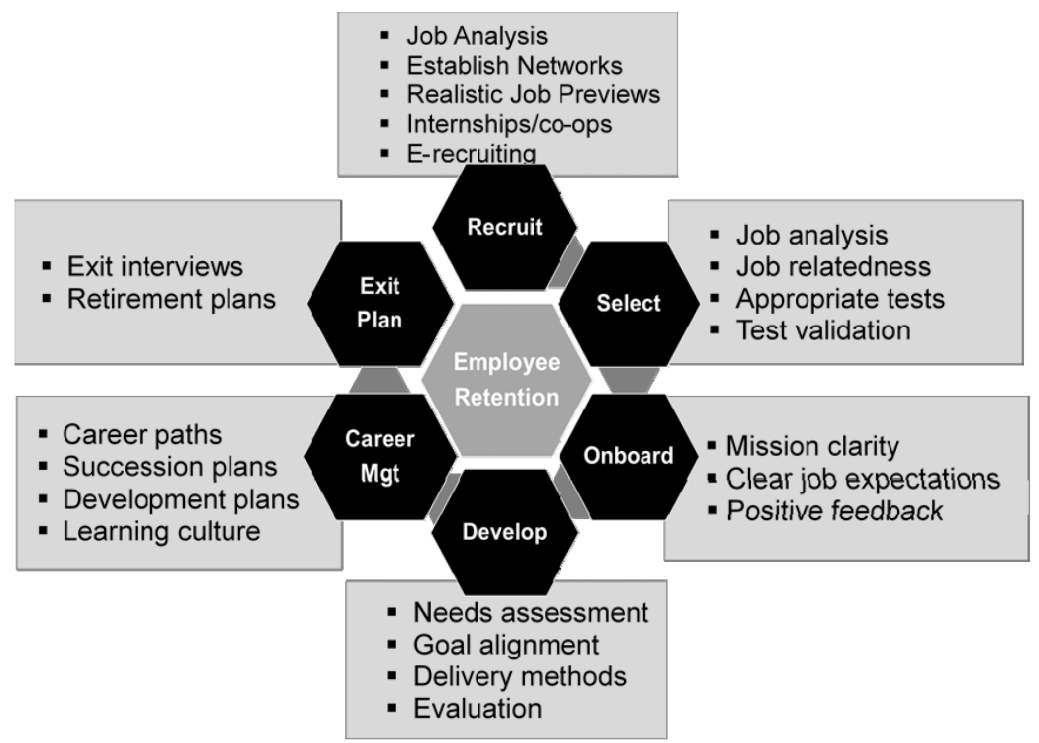




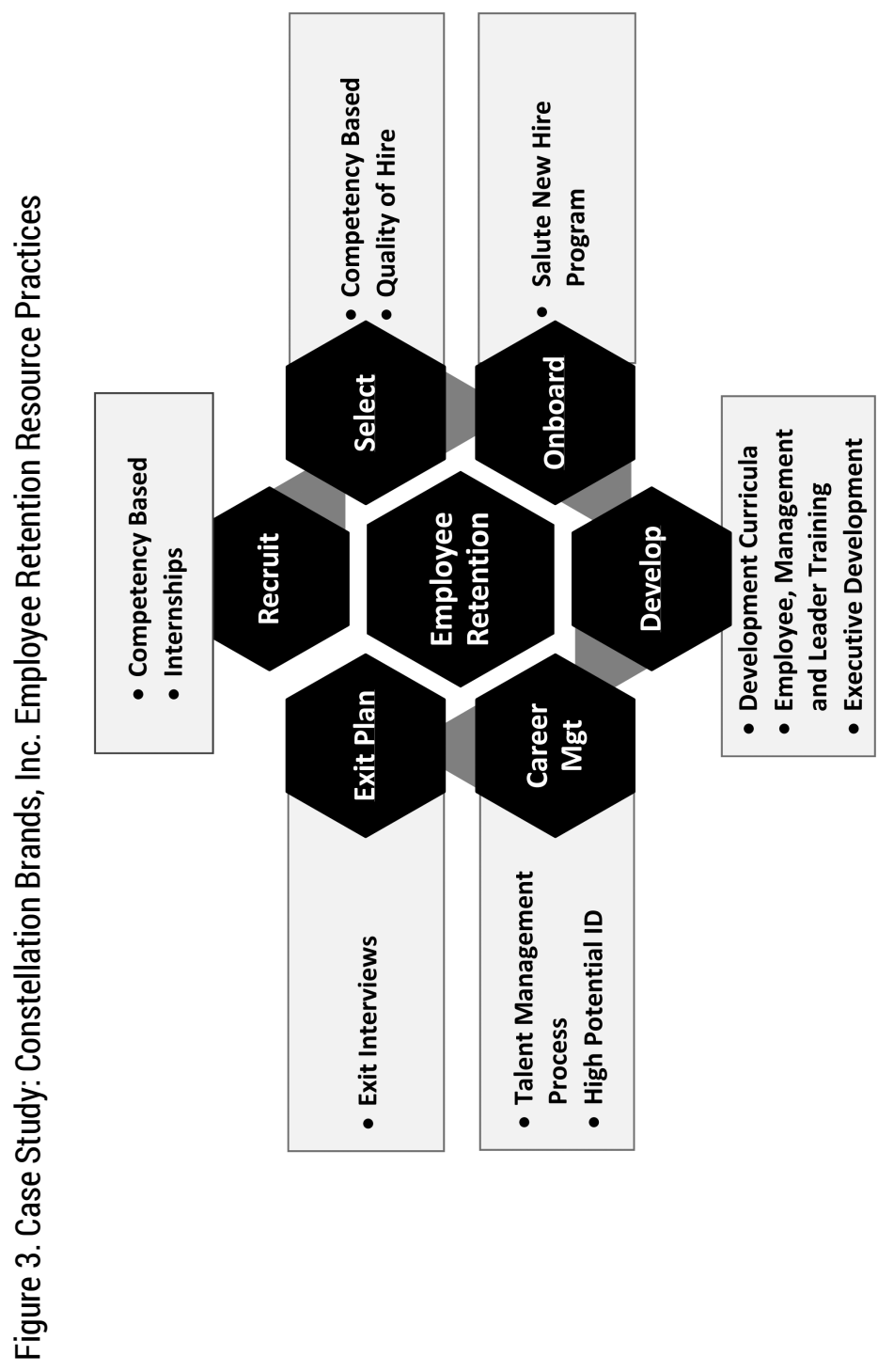




\section{REFERENCES}

Abo-Zaid, S. (2014). Net job creation in the US economy: Lessons from monthly data, 1950-2011. Applied Economics, 46(22), 2623-2638.

Ahmed, S. F., Pavani, K. L., \& Kumar, S. C. (2014). A study on employee commitment in private banking sector. International fournal of Organizational Behavior \& Management Perspectives, 3(4), 1227-1233.

Alameddine, M., Baumann, A., Laporte, A., \& Deber, R. (2012). A narrative review on the effect of economic downturns on the nursing labor market: Implications for policy and planning. Human Resources for Health, 10, 23-30. doi:http://dx.doi.org/10.1186/1478-4491-10-23.

Alexandrov, A., Babakus, E. \& Yavas, U. (2007), "The effects of perceived management concern for frontline employees and customers on turnover intentions". Journal of Service Research, 9(4), 356-371.

Baek-Kyoo, J., \& Ready, K. J. (2012). Career satisfaction. Career Development International, 17(3), 276-295. doi:http:// dx.doi.org/10.1108/13620431211241090.

Baur, J. E., Buckley, M. R., Bagdasarov, Z., \& Dharmasiri, A. S. (2014). A historical approach to realistic job previews. Fournal of Management History, 20(2), 200-223. doi:http://dx.doi.org/10.1108/ JMH-06-2012-0046.

Becker, B.E., Huselid, M.A., \& Ulrich, D. The HR Scorecard: Linking People, Strategy and Performance. Boston, Ma: Harvard Business School Press, 2001.

Berger, I. E., Cunningham, P. M., \& Drumwright, M. E. (2006). Identity identification and relationship through social alliances. Journal of the Academy of Marketing Sciences, 34(2), 128-137.

Bureau of Labor Statistics (2015). January jobless rates down in 24 states, up in 8; payroll jobs up in 39 states, down in 10. Retrieved March 17, 2005 from http://www.bls.gov/.

Cable, D. M., Gino, F., \& Staats, B. R. (2013). Reinventing employee onboarding. MIT Sloan Management Review, 54(3), 23-28. 
Camacho, M., Quiros, G. P., \& Mendizabal, H. R. (2011). High-growth recoveries, inventories and the great moderation. Fournal of Economic Dynamics \& Control, 35(8), 1322-1339.

Constellation Brands (2016). About Constellation Brands, Inc. Retrieved January 6, 2016 from http://www.cbrands.com/investors.

Coombs, J. (2015). Wages Stagnate Despite Thriving Job Market. SHRM HR Week, Retrieved March 10, 2015 from https:/www.shrm.org/ hrdisciplines/staffingmanagement/articles/pages/wages-stagnatethriving-job-market.aspx.

Earnest, D. R., Allen, D. G., \& Landis, R. S. (2011). Mechanisms linking realistic job previews with turnover: a meta-analytic path analysis. Personnel Psychology, 64(4), 865-897.

Fleig-Palmer, M., \& Rathert, C. (2015). Interpersonal mentoring and its influence on retention of valued health care workers: The moderating role of affective commitment. Health Care Management Review, 40(1), 56-64.

Flynn, W.J., Mathis, R.L., Jackson, J.H. \& Valentine, S.R. (2016). Healthcare Human Resource Management. Cengage Learning, Boston, Mass.

Friedman, B.A. (2009). Human Resource Management Role Implications for Corporate Reputation. Corporate Reputation Review. 12(3), 229-244.

Friedman, B.A. (2007). Globalization Implications for Human Resource Roles. Employee Responsibilities and Rights fournal, 19, 157-171.

Giannetti, M., \& Metzger, D. (2015). Compensation and competition for talent: Evidence from the financial industry. Finance Research Letters, 12, 11-16.

Graybill, J. O., Hudson Carpenter, M. T., Offord, J., Piorun, M., \& Shaffer, G. (2013). Employee onboarding: Identification of best practices in ACRL libraries. Library Management, 34(3), 200-218. doi:http:// dx.doi.org/10.1108/01435121311310897.

Halzack, S. (2014, May 09). Online tests are the latest gateway to landing a new job (posted 2014-05-09 02:05:17). The Washington Post. Retrieved 


\section{The BRC Academy Journal of Business Vol. 6, No. 1}

on March 10, 2015 from http://ezproxy.oswego.edu:2048/login?url= http://search.proquest.com/docview/1522647137?accountid=13025.

Huffcutt, A. I., \& Woehr, D. J. (1999). Further analysis of employment interview validity: A quantitative evaluation of interviewer-related structuring methods. fournal of Organizational Behavior, 20(4), 549-560.

Inabinett, J.M. \& Ballaro, J. M. (2014). Developing an organization by predicting employee retention by matching corporate culture with employee's values: A correlation study. Organization Development fournal, 32(1), 55-74.

Information Resources Incorporated (2015). Confidential CPG sector analysis. Retrieved on Jan 5, 2016 from https://www.iriworldwide. com/en-US/solutions/market-performance-and-strategy/marketmeasurement.

Kelly (2012). Acquisition and retention in the war for talent. Kelly Global Workforce Report. Retrieved on March 5, 2015 from http://www.kellyocg.com/uploadedFiles/Content/ Knowledge/ Kelly_Global_Workforce_Index_Content/Acquisition\%20and \%20Retention\%20in\%20the\%20War\%20for\%20Talent\%20Report.pdf.

Kim, J., Wehbi, N., DelliFraine, J.L. \& Brannon, D. (2014). The joint relationship between organizational design factors and HR practice factors on direct care workers' job satisfaction and turnover intent. Health Care Management Review, 39(2), 174-184. DOI: 10.1097/ HMR.0b013e31828c8b8f.

Korsakiene, R., Stankeviciene, A., Simelyte, A., \& Talackiene, M. (2015). Factors driving turnover and retention of information technology professionals. Journal of Business Economics and Management, 16(1), DOI 1. 10.3846/16111699.2015.984492.

Kraemer, T., \& Matthias H.J. Gouthier. (2014). How organizational pride and emotional exhaustion explain turnover intentions in call centers. Journal of Service Management, 25(1), 125-148. doi:http:// dx.doi.org/10.1108/JOSM-07-2013-0173.

Kusuma, P. G., \& Sukanya, M. (2013). Research synthesis on employee engagement strategies. International fournal of Organizational 
Behavior \& Management Perspectives, 2(4), 661-666. Retrieved from http://ezproxy.oswego.edu:2048/login?url= http://search.proquest. com.ezproxy.oswego.edu:2048/docview/1648119180?accountid=130 25

Jackson, H.G. (2015). Three signs of economic recovery. HR Magazine, 60(2), 8.

Lambert, E.G., Cluse-tolar, T., Pasupuleti, S., Prior, M. \& Allen, R.I. (2012). A Test of a Turnover Intent Model. Administration in Social Work, 36, 67-84, DOI: $10.1080 / 03643107.2010 .551494$.

Lazear, E. P., \& Spletzer, J. R. (2012). Hiring, churn, and the business cycle. The American Economic Review, 102(3), 575-579.

Leamer E: What's a Recession, Anyway? National Bureau of Economic Research Working Paper Series 2008, 14221:1-36.

March, J., \& Simon, H. (1958). Organizations. New York: Wiley.

Maurer R. (2015a). Planned layoffs off 5\%. SHRM HR Week. Retrieved on March 10, 2015 from http://www.shrm. org/hrdisciplines/staffingmanagement/articles/pages/plannedlayoffs-down-feb 2015.aspx?utm_source $=$ HR\%20Week\%20March $\% 209 \% 202015 \% 20$ (1) \&utm_medium=email\&utm_content=March $\% 2009, \% 202015 \&$ s p M a il in g I D = $22259705 \& \mathrm{sp}$ UserID=ODY2OTYwMDc3MDAS1\&spJobID=521003601\&spReportId=NTIx MDAzNjAxSo.

Maurer R. (2015b). Payrolls Exceed Forecast, Unemployment Dips to 5.5\%. SHRM HR Week. Retrieved on March 10, 2015 from https://www. shrm.org/hrdisciplines/staffingmanagement/articles/pages/payrollsforecast-unemployment-dips.aspx.

Maurer, T.J., \& Solamon, J.M. (2006). The science and practice of a structured employment interview coaching program. Personnel Psychology, 59(2), 433-456.

Melanthiou, Y., Pavlou, F., \& Constantinou, E. (2015). The use of social network sites as an E-recruitment tool. fournal of Transnational Management, 20(1), 31. DOI: 10.1080/15475778.2015.998141.

Elkjaer, D., \& Filmer, S. (2015). Trends and drivers of workforce turnover. Mercer Consulting. Retrieved January 12, 2016 from 
http://www.mercer.com/content/dam/mercer/attachments/global/ webcasts/trends-and-drivers-of-workforce-turnover-results-frommercers-2014-turnover-survey.pdf.

Milman, A., \& Dickson, D. (2014). Employment characteristics and retention predictors among hourly employees in large US theme parks and attractions. International fournal of Contemporary Hospitality Management, 26(3), 447-469.

Mrkvicka, N. (2015, 01). 2014 benefits benchmarking. Benefits Magazine, 52, 12. Retrieved from http://ezproxy.oswego.edu:2048/login?url=http:// search.proquest.com.ezproxy. oswego.edu:2048/docview/1651468517? accountid $=13025$

Mobley, W. H. (1977). Intermediate linkages in the relationship between job satisfaction and employee turnover. Journal of Applied Psychology, 62, 237-240.

Mobley, W., Griffeth, R., Hand, H., \& Meglino, B. (1979). Review and conceptual analysis of the employee turnover process. Psychological Bulletin, 86, 493-522.

Moreno, L. R. M., Torres, V. G. L., \& Vargas, M. E. M. (2015). Comportamiento de la tasa de rotación laboral en la industria maquiladora en Mexicali, Baja California, 2009-2013/behavior of labor turnover rate at the maquila industry in Mexicali, Baja California, 2009-2013. Revista Global De Negocios, 3(4), 11-26.

Moscarini, G., \& Postel-Vinay, F. (2012). The Contribution of Large and Small Employers to Job Creation in Times of High and Low Unemployment. American Economic Review, 102(6), 2509-2539. http:// dx.doi.org/10.1257/aer.102.6.2509.

Neal, J. G. (1989). Employee turnover and the exit interview. Library Trends, 38(1), 32.

Peter, I. A., \& Eunice, A. E. (2014). The link between human resource management practices and organizational commitment. Indian fournal of Management Science, 4(1), 10-18.

Price, J. L. (1977). The study of turnover. Ames: Iowa State University Press, Coral Springs, Florida. 
Reinstein, A., Sinason, D. H., \& Fogarty, T. J. (2012). Examining mentoring in public accounting organizations. Review of Business, 33(1), 40-49.

Santora, J. (2009). Quality management and manufacturing performance: Does success depend on firm culture? Academy of Management Perspectives, 23(2), 103-105.

Schmidt, F. L., \& Rader, M. (1999). Exploring the boundary conditions for interview validity: Meta-analytic validity findings for a new interview type. Personnel Psychology, 52(2), 445-464.

Singh, P., \& Natasha, L. (2010). Pay Satisfaction, Job Satisfaction and Turnover Intent. Relations Industrielles, 65(3), 470-490.

SHRM (2013a). Future Insights: The top trends for 2012 according to SHRM's HR subject matter expert panels. Retrieved January 1, 2013 from http://www.shrm.org/ Research/FutureWorkplaceTrends/ Documents/11-0622\%20Workplace\%20 panel_trends_symp\%20v4.pdf.

SHRM (2013b). HR Benchmarks Trendbook. Retrieved January 1, 2013 from http://online.qmags.com/HRM1212T\#pg1\&mode2.

Slack, R. E., Corlett, S., \& Morris, R. (2015). Exploring employee engagement with (corporate) social responsibility: A social exchange perspective on organizational participation. fournal of Business Ethics, 127(3), 537-548. doi:http:// dx.doi.org.ezproxy.oswego.edu:2048/10.1007/s10551-014-2057-3

Smith, L. G. E., Amiot, C. E., Smith, J. R., Callan, V. J., \& Terry, D. J. (2013). The social validation and coping model of organizational identity development: A longitudinal test. Fournal of Management, 39(7), 1952-1978. doi:http://dx.doi.org/10.1177 /0149206313488212.

Steel, R., \& Ovalle, N. (1984). A review and meta-analysis of research on the relationship between behavioral intentions and employee turnover. Fournal of Applied Psychology, 69, 673-686.

Summary Annual Report (2015). The sky is the limit Constellation Summary Annual Report. Retrieved December 28, 2015 from http://www.cbrands. $\mathrm{com} / \mathrm{sites} /$ default/files/2015\%20Annual\%20Report\%20.pdf.pdf 
Summers, L. H. (2010). Principles for economic recovery and renewal. Business Economics, 45(1), 3-7. doi:http://dx.doi.org/10.1057/be.2009.41.

Swarnalatha, C., \& Prasanna, T. S. (2013). Leveraging employee engagement for competitive advantage: Strategic role of HR. Review of HRM, 2, 139-148. Retrieved from http://ezproxy.oswego.edu:20 48/login?url=http://search.proquest.com.ezproxy.oswego.edu:2048/ docview/1655997743? accountid=13025

Tekleab, A. G., Orvis, K. A., \& Taylor, M. S. (2013). Deleterious consequences of change in newcomers' employer-based psychological contract obligations. fournal of Business and Psychology, 28(3), 361-374. doi:http://dx.doi.org/10.1007/s10869-012-9277-2.

Timms, C., Brough, P., O'Driscoll, M., Kalliath, T., Siu, O. L., Sit, C., \& Lo, D. (2015). Flexible work arrangements, work engagement, turnover intentions and psychological health. Asia Pacific Journal of Human Resources, 53(1), 83.

Treuren, G. J. M., \& Frankish, E. (2014). Pay dissatisfaction and intention to leave: The moderating role of personal care worker client embeddedness. Nonprofit Management and Leadership, 25(1), 5.

Turker, D. (2009b). How corporate social responsibility influences organizational commitment. Journal of Business Ethics, 89(2), 189-204.

Udechukwu, I. I., \& Mujtaba, B. G. (2007). Determining the probability that an employee will stay or leave the organization: A mathematical and theoretical model for organizations. Human Resource Development Review, 6(2), 164-184.

Urlich, D. HR Champions. Boston, Ma: Harvard Business Press, 1997.

Vafeas, M. (2015). Account manager turnover and the influence of context: An exploratory study. The fournal of Business \& Industrial Marketing, 30(1), 72-82.

Wang, Y., Hu, C., Hurst, C. S., \& Yang, C. (2014). Antecedents and outcomes of career plateaus: The roles of mentoring others and proactive personality. Fournal of Vocational Behavior, 85(3), 319-328.

Wanous J.P., (1980). Organizational entry: Recruitment, selection and socialization of newcomers. Reading MA: Addison-Wesley. 
Wanous J.P., Poland, T.D., Premack, S.L., Davis, K.S. (1992). The effects of met expectations on newcomer attitudes and behaviors: A review and meta-analysis. Journal of Applied Psychology, 77, 288-297.

Wheeler, A.R., Harris, K.J., \& Harvey, P. (2010). Moderating and Mediating the HRM Effectiveness - Intent to Turnover. Journal of Managerial Issues, 22(2), 182-196.

Wheeler, A.R., Halbesleben, J.R.B., \& Harris, K.J. (2012). How joblevel HRM effectiveness influences employee intent to turnover and workarounds in hospitals. Journal of Business Research, 65, 547-554. doi:10.1016/j.jbusres.2011.02.020.

Yean, T. F., \& Yahya, K. K. (2013). The influence of human resource management practices and career strategy on career satisfaction of insurance agents. International fournal of Business and Society, 14(2), 193-206.

\section{Citation Information}

Friedman, Barry A., and Lisa M. Schnorr. "Latent Employee Turnover and Prevention: When Job Creation Catches Up with Economic Recovery: An Employee Retention Model and Case Study." The BRC Academy Journal of Business 6, no. 1 (2016): 1-29. http://dx.doi.org/10.15239/ j.brcacadjb.2016.06.01.ja01 
